Theoretical-empirical Article

\title{
Marketing Investment Information: Differentiation Resource or Secret?
}

\author{
Informações dos Investimentos de Marketing: Recurso de Diferenciação ou \\ Segredo?
}

\author{
Evelini Lauri Morri Garcia*1 $\odot$ \\ Valter Afonso Vieira ${ }^{2} \bullet$ \\ Caroline Pereira Borges ${ }^{3 \oplus}$
}

\section{ABSTRACT}

Objective: drawing on voluntary disclosure theory, the paper's main goal was to analyze the main effect of marketing intensity and the moderating role of life cycle on disclosure of marketing investments. Method: the sample includes 89 Brazilian companies listed on B3 stock exchange. We collected financial data from two sources, such as Economatica platform and in the explanatory notes and management report from the companies, which we coded through content analysis. We merged these two datasets and analyzed it using multiple linear regression. Results: both the marketing intensity and the life cycle of companies have effects on disclosure of marketing investments. In addition, the birth and growth phases moderate the main effect of marketing intensity, reducing the level of disclosure. This moderation is identified especially in disclosures of qualitative information. Conclusions: the findings support the voluntary disclosure theory based on arguments of judgment-based disclosure. Outcomes showed that when there is a high intensity of marketing investments, disclosure of marketing investments is managed by moving from the status of secrecy in companies in the birth and growth phases of life cycle to the status of differentiation resource in companies in the maturity phase of life cycle.

Keywords: marketing information; disclosure; intensity of marketing investments; life cycle.

\section{RESUMO}

Objetivo: tomando por base a voluntary disclosure theory, o objetivo desta pesquisa foi analisar os efeitos da intensidade dos investimentos de marketing e do ciclo de vida das empresas no disclosure dos investimentos de marketing. Método: a amostra possui dados financeiros de 89 companhias brasileiras listadas na Bolsa B3 (Economatica) unificados com dados dos investimentos de marketing das empresas (notas explicativas e relatório da administraçáo). Resultados: tanto a intensidade dos investimentos de marketing como o ciclo de vida das empresas influenciam o disclosure dos investimentos de marketing. As fases de nascimento e crescimento moderam os efeitos da intensidade dos investimentos de marketing, diminuindo o nível de disclosure, especialmente em informaçóes qualitativas. Conclusóes: os achados sustentam a voluntary disclosure theory e são baseados em argumentos de julgamento porque mostram que, existindo alta intensidade de investimentos de marketing, o disclosure dos investimentos de marketing é gerenciado passando do status de segredo em empresas que estão nas fases de nascimento e crescimento para o status de recurso de diferenciaçáo em empresas na fase de maturidade.

Palavras-chave: informaçóes de marketing; disclosure; intensidade de investimentos de marketing; ciclo de vida.

\footnotetext{
* Corresponding Author.

1. Universidade Estadual de Maringá, Programa de Pós-graduação em Ciências Contábeis, Maringá, PR, Brazil. 2. Universidade Estadual de Maringá, Programa de Pós-graduação em Administração, Maringá, PR, Brazil. 3. Universidade Estadual de Maringá, Departamento de Ciências Contábeis, Maringá, PR, Brazil.

Cite as: Garcia, E. L. M., Vieira, V. A., \& Borges, C. P. (2022). Marketing investment information: Differentiation resource or secret? Revista de Administração Contemporânea, 26(2), e200386. https://doi.org/10.1590/1982-7849rac2022200386.en
}

\section{\# of invited reviewers until the decision:}

\# of invited reviewers until the decision:
$1^{\text {st }}$ round
$2^{\text {nd }}$ round
$3^{\text {rd }}$ round

$\overbrace{0}^{9}$

JEL Code: M310, M480, G300.

Editors-in-chief: Wesley Mendes-da-Silva (Fundação Getulio Vargas, EAESP, Brazil) (c) Marcelo de Souza Bispo (Universidade Federal da Paraíba, PPGA, Brazil) Associate Editor: Emílio José M. Arruda Filho (Universidade da Amazônia, Brazil) Reviewers: The reviewers did not authorize the disclosure of their identities. Peer Review Report: The disclosure of the Peer Review Report was not authorized by its reviewers.

Received: November 17, 2020 Last version received: April 26, 2021 Accepted: May 21, 2021 


\section{INTRODUCTION}

For investors to be able to assess the impact of marketing strategies on performance, there must be marketing investment disclosure (Bayer, Tuli, \& Skiera, 2017). The definition of marketing investment disclosure is the public disclosure of qualitative and quantitative information on investments made in marketing through accounting reports (for example, research and development investments, communication, customer loyalty, etc.) (Stewart, 2009). The greater the marketing information disclosure, with retrospective and prospective analyses, the lesser the uncertainties of investors regarding the future performance of the firm (Joshi \& Hanssens, 2010; Ma, Dewally, \& Huang, 2017).

Accounting standards do not require disclosure of the details of marketing investments, allowing each firm to determine the level of knowledge that investors will access about marketing strategies (Bayer et al., 2017). The motivation for the voluntary disclosure of marketing investments is the requirement to align the expectations of the financial market with the firm's private information (Koo \& Lee, 2018), justifying its capacity to create value (Silveira, Oliveira, Heldt, \& Luce, 2020) and its market value (Dye, 2001).

Despite the theoretical arguments that the marketing investment disclosure generates benefits for investors and firms, this disclosure involves a trade-off (Bayer et al., 2017). On the one hand, the marketing investment disclosure can be a differentiating feature because it allows investors to compare and evaluate competing companies, using information related to marketing activities as a sign of the quality of organizational management (Simpson, 2008) and the CEO's stance (Koo \& Lee, 2018). On the other hand, the marketing investment disclosure can 'erode' the organizational capacity to build and sustain competitive advantage, revealing organizational 'secrets' (Sidhu \& Roberts, 2008), given that marketing investments are strategic actions and the publication of these data can trigger mimicry in competing companies (Mohamed \& Schwienbacher, 2016).

There is a relationship between the marketing investment disclosure and two constructs. One is the marketing investment intensity defined as the company's spending on strategic marketing actions (Markovitch, Huang, \& Ye, 2020). The theory in marketing suggests that the greater the financial resource allocated to marketing, the greater the value of the company (Luo, 2008) and the more disclosure should therefore be practiced to justify these investments (Edeling,
Srinivasan, \& Hanssens, 2020). The second construct is the organization's life cycle defined as the company's life stages, being the beginning (birth and growth), maturity, and decline (turbulence and decline) (Dickinson, 2011). Investors' understanding of the marketing investment intensity can vary widely across the different stages of the firm's life cycle because of the characteristics of each of these phases (Cantrell \& Dickinson, 2020; Krishnan, Myllymäki, \& Nagar, 2021).

Although previous studies have shown that the marketing investment intensity instigates investor perception because it increases the firm's market value (McIlkenny \& Persaud, 2017) and drives transparency practices (Ma et al., 2017), there are no studies in the literature on the influence of the marketing investment intensity on the level of marketing disclosure (see Table 1). Another limitation is that the few studies on disclosure of marketing investments have only considered information on advertising investments (Edeling et al., 2020).

Considering that a gap remains in the studies regarding the paradox of marketing information in being a 'differentiation resource' or 'secret' (Shi, Grewal, \& Sridhar, 2021), we seek in this study to answer the following research question: "What are the direct effects of the marketing investment intensity and the moderating role of the life cycle on the level of marketing investment disclosure?" While previous studies have highlighted the value of marketing investments as a driver of investor perception (Bae, Kim, \& Oh, 2017; Fine, Gleason, \& Mullen, 2017) and the life cycle as a determinant of the quality of accounting reports (Bakarich, Hossain, \& Weintrop, 2019; Kabir, Su, \& Rahman, 2020; Krishnan et al., 2021), our study addresses how the marketing investment intensity conditioned by the phases of the life cycle interfere in the detailing of information disclosed about the strategies that underlie marketing investments that can influence investors' decisions.

Using secondary data from 89 Brazilian companies listed on B3, the survey presents three contributions to the voluntary disclosure theory. First, we demonstrate that the marketing investment intensity positively influences the level of marketing investment disclosure. Second, we demonstrate that companies in the early stages of the life cycle (birth and growth) carry out greater volumes of marketing investment disclosure than other phases. Third, we reveal that the greater the marketing investment intensity, the lower the level of disclosure in firms that are in the stages of birth and growth (vs. maturity, turbulence, and decline). The understanding of this finding is supported by the theoretical concepts of a voluntary disclosure based on judgment (Verrecchia, 
2001), since the status of a resource for differentiating information from marketing investments, when there is a high intensity of marketing investments, passes to the status of secrecy in companies that are in the birth and growth stages. Under the voluntary disclosure theory, the present study contributes to the understanding that marketing disclosure is manipulated based on the costs and risks that this information generates in each phase that the companies are in.

Table 1. Previous studies.

\begin{tabular}{|c|c|c|c|c|c|c|c|}
\hline \multirow[b]{2}{*}{ Authors } & \multicolumn{3}{|c|}{ Constructs } & \multicolumn{3}{|c|}{$\begin{array}{l}\text { Positioning in the } \\
\text { conceptual model }\end{array}$} & \multirow[b]{2}{*}{ Main findings } \\
\hline & $\begin{array}{c}\text { Marketing } \\
\text { investment } \\
\text { disclosure }\end{array}$ & $\begin{array}{c}\text { Marketing } \\
\text { investment } \\
\text { intensity }\end{array}$ & $\begin{array}{l}\text { Life } \\
\text { cycle }\end{array}$ & Dep. & Ind. & Mod. & \\
\hline $\begin{array}{l}\text { Bae, Kim and } \mathrm{Oh} \\
(2017)\end{array}$ & & $\checkmark$ & & & & $\checkmark$ & $\begin{array}{l}\text { Marketing investment intensity moderated positively the relationship } \\
\text { between financial leverage and Tobin's Q. }\end{array}$ \\
\hline $\begin{array}{l}\text { Bakarich, Hossain } \\
\text { and Weintrop } \\
(2019)\end{array}$ & & & $\checkmark$ & & $\checkmark$ & & $\begin{array}{l}\text { The life cycle is a determinant (driver) of the qualitative characteristics } \\
\text { of information disclosed in the annual reports. }\end{array}$ \\
\hline $\begin{array}{l}\text { Bayer, Tuli and } \\
\text { Skiera (2017) }\end{array}$ & $\checkmark$ & & & & $\checkmark$ & & $\begin{array}{l}\text { The greater the marketing information disclosure related to customer } \\
\text { equity metrics, the lower the uncertainty for investors and analysts. }\end{array}$ \\
\hline $\begin{array}{l}\text { Cantrell and } \\
\text { Dickinson (2020) }\end{array}$ & & & $\checkmark$ & & $\checkmark$ & & $\begin{array}{l}\text { Retardant competitors in the same life cycle gain advantages by } \\
\text { repeating the marketing investment strategies of leading firms. }\end{array}$ \\
\hline Dickinson (2011) & & & $\checkmark$ & & & $\checkmark$ & $\begin{array}{l}\text { The asset turnover and profit margin are differentially successful in } \\
\text { generating increases in profitability conditional on the life cycle stage. }\end{array}$ \\
\hline $\begin{array}{l}\text { Fine, Gleason and } \\
\text { Mullen (2017) }\end{array}$ & & $\checkmark$ & & & $\checkmark$ & & $\begin{array}{l}\text { Pre-IPO marketing investments positively impact the performance of } \\
\text { short-term actions. }\end{array}$ \\
\hline $\begin{array}{l}\text { Kabir, Su and } \\
\text { Rahman (2020) }\end{array}$ & & & $\checkmark$ & & $\checkmark$ & & $\begin{array}{l}\text { Mature companies disclose more impairment test information than } \\
\text { companies in other life cycle stages, such as the introduction, growth, } \\
\text { and decline stages. }\end{array}$ \\
\hline $\begin{array}{l}\text { Krishnan, } \\
\text { Myllymäki and } \\
\text { Nagar (2021) }\end{array}$ & & & $\checkmark$ & & $\checkmark$ & & $\begin{array}{l}\text { Companies in the introduction, growth, and decline stages are } \\
\text { significantly more likely to have distortions in their financial statements } \\
\text { compared to companies in the maturity stage. }\end{array}$ \\
\hline $\begin{array}{l}\text { Ma, Dewally and } \\
\text { Huang (2017) }\end{array}$ & & $\checkmark$ & & $\checkmark$ & $\checkmark$ & & $\begin{array}{l}\text { Companies whose shares are valued (devalued) spend more (less) on } \\
\text { marketing in the five years after the IPO. The marketing investment } \\
\text { intensity positively influences the transparency of company information } \\
\text { after the IPO. }\end{array}$ \\
\hline $\begin{array}{l}\text { Markovitch, Huang } \\
\text { and Ye }(2020)\end{array}$ & & $\checkmark$ & & & $\checkmark$ & & $\begin{array}{l}\text { There is a positive relationship between marketing intensity and the } \\
\text { indices that measure the current and future performance of firms. }\end{array}$ \\
\hline $\begin{array}{l}\text { McIlkenny and } \\
\text { Persaud (2017) }\end{array}$ & $\checkmark$ & & & & $\checkmark$ & & $\begin{array}{l}\text { There is a positive relationship between the advertising expenses } \\
\text { disclosure and the company's value. However, it depends on the size } \\
\text { and the industry of the company. }\end{array}$ \\
\hline $\begin{array}{l}\text { Shi, Grewal and } \\
\text { Sridhar (2021) }\end{array}$ & $\checkmark$ & & & & $\checkmark$ & & $\begin{array}{l}\text { Companies can use the disclosure of competitors marketing } \\
\text { information to condition their disclosure and their strategic advantage } \\
\text { in the product and financial market. }\end{array}$ \\
\hline Simpson (2008) & $\checkmark$ & & & $\checkmark$ & & & $\begin{array}{l}\text { Companies with low (high) advertising evaluation benefits during } \\
\text { the mandatory disclosure period are less (more) likely to voluntarily } \\
\text { disclose their advertising expenses. }\end{array}$ \\
\hline \multirow{3}{*}{ This study } & $\checkmark$ & & & $\checkmark$ & & & \multirow{3}{*}{$\begin{array}{l}\text { The marketing investment intensity and the life cycle of companies } \\
\text { influence the marketing investment disclosure. }\end{array}$} \\
\hline & & $\checkmark$ & & & $\checkmark$ & & \\
\hline & & & $\checkmark$ & & $\checkmark$ & $\checkmark$ & \\
\hline
\end{tabular}

Note. Dep. = dependent variable; Ind. = independent variable; Mod. = moderating variable or conditioning element. 


\section{THEORETICAL BACKGROUND}

\section{Voluntary disclosure theory}

Voluntary disclosure theory suggests that disclosure of information beyond mandatory criteria helps stakeholders make decisions (Mcllkenny \& Persaud, 2017), reduces the cost of external financing, and improves a company's ability to leverage capital for potentially profitable projects (Verrecchia, 2001). Voluntary disclosure theory also presents the effects of the tension between the value of more detailed information for the investor and the costs of this disclosure (Dye, 2001). As both markets - capital and products (competitors) - observe the disclosures of companies (Simpson, 2008), the voluntary disclosure theory explains and predicts that the decision to disclose organizational information involves a trade-off between the possibility of strong competitors and foster benefits of a more reliable assessment for stakeholders (Dye, 2001). When the costs of disclosure outweigh the benefits, there is a potential barrier to broader disclosures (Verrecchia, 2001).

Voluntary disclosure theory argues that companies' financial reports should disclose marketing information because they reduce the uncertainty of investors and analysts (Bayer et al., 2017; Sidhu \& Roberts, 2008), which makes this disclosure a relevant resource for the financial market (Stewart, 2009). However, current accounting standards suggest, without requiring, that the notes or management report disclose (a) the marketing assets off-balance sheet, (b) the resources and budgets directed to marketing investments, (c) information related to the growth or decrease of marketing investments and (d) the respective effects on the company's results, and (e) the investment outlook for the next periods and the expected future results for the current investments (see more details in Appendix A). Therefore, any disclosure about the financial resources that were employed or obtained through marketing efforts, or even any nonfinancial measure corresponding to these activities, is voluntary disclosure (McIlkenny \& Persaud, 2017).

Previous studies reported that the breadth of voluntary disclosure of marketing investments is linked to operating results (Simpson, 2008), market value (McIlkenny \& Persaud, 2017) and the 'herd effect' in the voluntary information disclosure (Shi et al., 2021). However, when a company does not disclose marketing investments, investors cannot assess marketing expenditures (Shi et al., 2021). Based on this dilemma, the analysis of the determinants of the marketing investment disclosure is important because the lack of information generates doubts on the financial market and can impose real costs on investors (Simpson, 2008).

\section{Marketing investment intensity}

Marketing investment intensity is defined as the financial value of investments in the most varied marketing activities (McIlkenny \& Persaud, 2017), which influences the company's market value because it impacts sales revenue and profit (Bae et al., 2017). There is also a relationship between the marketing investment intensity and the assessment of the company by investors (Oh, Gulen, Kim, \& Robinson, 2016). For example, Luo (2008) and Fine et al. (2017) found that the increase in the marketing investment intensity in the period before the initial public offering (IPO) helps reduce information asymmetry and results in less underpricing.

Although the literature demonstrates that the marketing investment intensity is capable of influencing the company's market value because of the ability to signal investors to the firm's financial status (Bae et al., 2017; Markovitch et al., 2020), there is little discussion about the relationship between marketing investment intensity and the level of disclosure from the empirical perspective. Marketing investment is relevant information for stakeholders because the benefits of marketing assets (Srivastava, Shervani, \& Fahey, 1998) are not immediately reflected in accounting performance and, therefore, more specific and detailed information about these investments can serve as additional signals about the company's future performance (Mizik, 2010).

As uncertainty generates problems of adverse selection, companies with greater investment intensity can carry out more marketing investment disclosure to reduce the asymmetry between the agent and the principal. Ma et al. (2017) found an association between the marketing investment intensity and the transparency of company information after an IPO. These positive results are expected because companies that invest more in marketing assets (Srivastava et al., 1998) can have competitive advantages and prioritize transparency and fearless competition (Mohamed \& Schwienbacher, 2016). However, there is a lack of studies that consider organizational life cycles (Shi et al., 2021) as moderating variables to explain the effects of the volume of investments in disclosure. 


\section{Life cycle}

The life cycle of companies is defined in five phases, being birth, growth, maturity, turbulence, and decline (Dickinson, 2011), although some authors add phases such as birth-growth and turbulence-decline (Mikosz, Roma, Louzada, \& Macedo, 2019). Each company is in a specific life cycle and these cycles vary in terms of financing needs, sales growth, profitability, the amount of resources available, and uncertainty regarding the environment (Cantrell \& Dickinson, 2020).

In this article, we specifically discuss the initial phase, which concentrates on the stages of birth and growth, in which new products normally enter the market and the firm arouses the attention of competitors, who start monitoring it (Costa, Macedo, Yokoyama, \& Almeida, 2017). When companies move from the birth stage to the growth stage, the pressure from competitors increases and there is a need to promote products on the market (Dickinson, 2011). To reach and sustain the birth and growth phases, companies invest in expansion and market segmentation, expanding the need for external financing (Kabir et al., 2020).

Companies in the birth and growth phases commonly have few financial resources available (Habib \& Hassan, 2019). However, the request for financing by companies in these phases is viewed with caution by the financial market, since (a) the results forecasts are of limited use due to the lack of history, (b) there are wide uncertainties regarding the firm's continuity, and (c) long-term planning may not be intentionally detailed so as not to attract the attention of competitors (Kabir et al., 2020). Thus, the search for external capital and the need to protect strategies can trigger different effects in the decision to disclose investment information during the birth and growth phases (Bayer et al., 2017).

On the one hand, the literature has shown that firms in the growth phase are more likely to disclose information on marketing investments to attract investors (Mohamed \& Schwienbacher, 2016) and there is also evidence that the disclosure policy is broader when the firm is financed mainly by external capital (Khurana, Pereira, \& Martin, 2006). On the other hand, the literature showed that companies in the birth and growth phases face more uncertainties than other companies, greater difficulty in carrying out voluntary disclosures (Kabir et al., 2020), inability to fully capture the benefits of their marketing efforts innovation (Cantrell \& Dickinson, 2020) and more complicated and ambiguous communication (Bakarich et al., 2019).

\section{HYPOTHESES}

\section{Direct effects}

We suggest that the greater the marketing investment intensity, the greater the level of marketing investment disclosure. Based on the voluntary disclosure theory (McIlkenny \& Persaud, 2017), this effect occurs because marketing investments can affect the company's value - increasing profits through increased sales increase the company's intangible value assessed by stakeholders (Joshi \& Hanssens, 2010; Sidhu \& Roberts, 2008; Srivastava et al., 1998). Companies that employ high volumes of marketing investments call the attention of the financial market, being charged for a higher level of transparency in disclosure (Stewart, 2009) to allow an assessment of their equity (Sidhu \& Roberts, 2008). Therefore, when increasing the marketing investment intensity, there is a greater need for information for the stakeholder to invest (Bae et al., 2017; Markovitch et al., 2020), reducing the information asymmetry between economic agents (Kabir et al., 2020) and generating greater data transparency (Dye, 2001). Therefore, we present the following hypothesis:

Hypothesis 1: The greater the marketing investment intensity, the greater the level of marketing investment disclosure.

We expect companies that are in the birth and growth stages to increase the marketing investment disclosure due to the more severe levels of uncertainty in investment results (Dickinson, 2011). Companies in the stages of birth and growth face problems such as lack of resources, low profitability, low remuneration for investors, among others (Costa et al., 2017), and have higher levels of information asymmetry compared to companies that are in other phases of the life cycle (Ma et al., 2017). As companies that face serious information asymmetry problems benefit most from communicating 'good' news to the market (Mohamed \& Schwienbacher, 2016), we expect companies that are in the birth and growth phases to also work harder to communicate the fundamentals of marketing investments to the market, minimizing the problem of asymmetry.

In addition, companies that are in the birth and growth stages have greater financial needs (Dickinson, 2011) and depend on external funds to finance their investments (Cantrell \& Dickinson, 2020). Consequently, the demand for transparency and accountability in financing (Dye, 2001) increases as companies seek external capital to sustain their investments (Stewart, 2009). Greater transparency helps companies reduce 
information asymmetries (Khurana et al., 2006) and offers security to investors, minimizing agency problems (Ma et al., 2017). Therefore, companies that are in the birth and growth phases tend to disclose more information than companies in other phases (Kabir et al., 2020). Therefore:

Hypothesis 2: Companies that are in the stages of birth and growth (vs. the stages of maturity, turbulence, and decline) of the life cycle have higher levels of marketing investment disclosure.

\section{Moderating effect of the life cycle}

We propose that when the marketing investment intensity increases, the level of marketing investment disclosure decreases in companies that are in the stages of birth and growth (compared with mature or turbulentdeclining companies). This hypothesis is centered on the recognition that companies, even though they are in the same stage of the life cycle, can adopt different strategies and different amplitudes of marketing investments (Cantrell \& Dickinson, 2020; McIlkenny \& Persaud, 2017) directing to specific postures regarding the information disclosure (Verrecchia, 2001).

The positive effect of the relationship between the marketing investments intensity and the level of investments disclosure changes to a negative effect by moderating the life cycle phases because companies in the birth and growth phases attract the attention of competitors and tend to be more competitive (Cantrell \& Dickinson, 2020). Competitors use marketing investment information in several ways preventing an accurate prediction of the consequences of such disclosure (Shi et al., 2021). For this reason, companies in the birth and growth phases of the life cycle may decide to 'hide' information regarding the use of high marketing investments. Another argument is that companies that are in the stages of birth and growth have difficulties convincing the market that the high investments presented will generate performance in the future and therefore can seek ways to omit those (Krishnan et al., 2021).

The voluntary disclosure theory proposes that companies in the stages of birth and growth have incentives not to make disclosures that could harm their competitive position in the market (Verrecchia, 2001). Although voluntary disclosures of high marketing investments are linked to companies' profit and equity (McIlkenny \& Persaud, 2017), such information also subsidizes the actions of competitors in the market (Khurana et al., 2006). Therefore, we conjecture that the marketing investment disclosure is more sensitive for companies in the phases of birth and growth (vs. other phases) because they experience greater sales growth, are trying to establish themselves in the market (Kabir et al., 2020) and seek to differentiate themselves from firms already established in their business segments.

Empirical evidence has shown that companies operating in competitive markets disclose less information (Mohamed \& Schwienbacher, 2016) because laggard companies can outperform the results of leading companies that are in the birth and growth phases by capturing and applying the same strategies, taking advantage of learning from actions employed by leading companies (Cantrell \& Dickinson, 2020). As marketing investments are strategic resources (Joshi \& Hanssens, 2010) and as competitors target companies in the birth and the growth phases (Khurana et al., 2006), we expect companies in these phases to consider high investment strategies from marketing as a 'secret' and do not disclose them. Thus, we present the following hypothesis:

Hypothesis 3: The greater the marketing investment intensity, the lower (vs. higher) the level of marketing investment disclosure in companies that are in the birth and growth phases (vs. in the stages of maturity, turbulence, and decline).

\section{METHODOLOGY}

\section{Sample}

The research sample consists of 89 Brazilian companies listed in Brasil Bolsa Balcão (B3), with 70 companies in the cyclical consumption sector and 19 companies in the non-cyclical consumption sector (Table 2). The sample cut is justified because marketing investments build greater equity for consumer goods companies, compared to companies in other sectors (Oh et al., 2016), and marketing investments can influence demand and consumption, impacting financial results (Sydney-Hilton \& Vila-Lopez, 2019). 


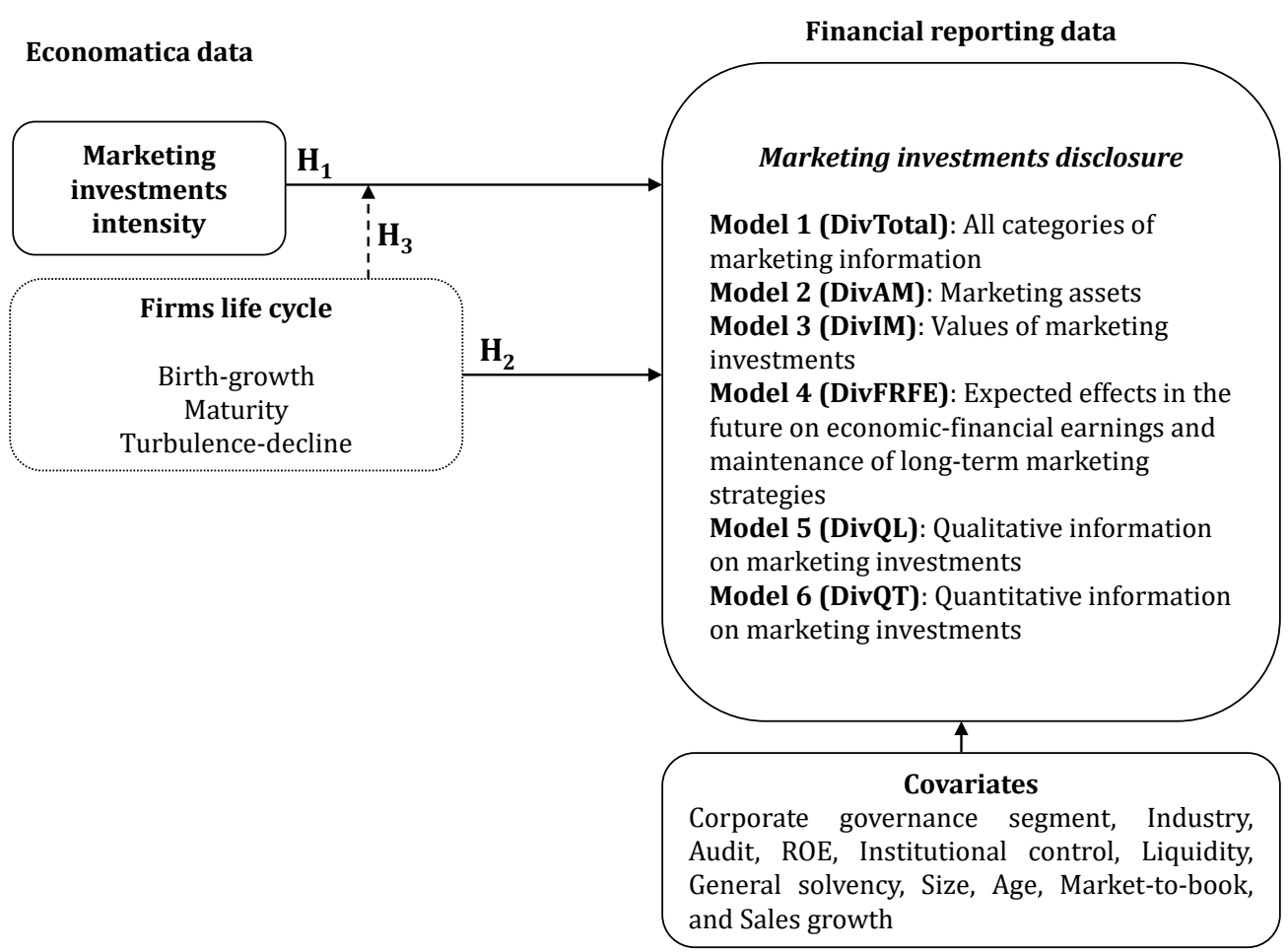

Figure 1. Theoretical framework.

Table 2. Research sample.

\begin{tabular}{|c|c|c|c|}
\hline Industry & Subindustry & Number of companies & Percent \\
\hline \multirow{9}{*}{ Cyclic consumption } & Automobiles and Motorcycles & 3 & $3 \%$ \\
\hline & Trade & 12 & $13 \%$ \\
\hline & Construction & 18 & $20 \%$ \\
\hline & Several & 8 & $9 \%$ \\
\hline & Hotels and Restaurants & 3 & $3 \%$ \\
\hline & Media & 1 & $1 \%$ \\
\hline & Fabrics, Clothing, and Footwear & 17 & $19 \%$ \\
\hline & Housewares & 3 & $3 \%$ \\
\hline & Travel and Leisure & 5 & $5 \%$ \\
\hline \multirow{5}{*}{ Non-cyclical consumption } & Agriculture & 4 & $4 \%$ \\
\hline & Processed Foods & 10 & $11 \%$ \\
\hline & Drinks & 1 & $1 \%$ \\
\hline & Commerce and Distribution & 2 & $2 \%$ \\
\hline & Personal Use and Cleaning Products & 2 & $2 \%$ \\
\hline Total & & 89 & $100 \%$ \\
\hline
\end{tabular}

\section{Research data}

The financial data are from the financial statements for the fiscal year ended December 31, 2018, and were accessed through the Economatica platform and the B3 stock exchange website and subsequently unified. We obtained data on marketing investment disclosure from the financial reports, the explanatory notes, and the management report for the 2018 fiscal year, characterizing, therefore, a study with cross-sectional data. 


\section{Codification of the marketing investment disclosure}

The dependent variable of this study is the level of marketing investment disclosure. We built this variable using the content analysis technique that aims to identify the essence of textual communication (Bardin, 1977). We analyzed voluntary disclosures suggested by regulatory bodies by identifying 12 categories of voluntary marketing information (Appendix A). The information in categories 1,2 , and 3 deals with off-balance sheet marketing assets. Categories 4 and 5 are information on resources and budgets directed to marketing investments. Categories $6,7,8$, and 9 are information related to the growth or decrease of marketing investments and the respective effects on the company's results. Finally, categories 10, 11, and 12 contain information related to the perspective of future investments and the expected results for the current investments.

We performed data collection by reading the financial reports and manual annotation in an electronic spreadsheet by the authors. We define categorization a priori considering that we follow the suggestions of the regulatory bodies. The technique used was thematic analysis (categorical), which identifies nuclei of the meaning of communication. The categorization criterion applied is the logical-semantic method, whose scope follows parameters and logical definitions. We apply binary coding to the data to make it possible to measure the information levels of marketing investments, assigning code 1 when the company performs the disclosure of information and code 0 for the absence of information (dummy). This binary coding allowed to measure the level of marketing investment disclosure in different perspectives (for example, marketing assets, marketing investments, financial and economic effects of marketing investments, and future perspectives) and to make inferences and interpretations considering subcategories, such as the types of information (qualitative or quantitative). The identification of the different perspectives of the information allowed subdividing the dependent variable into six distinct variables, generating six study models (Table 3 ).

Table 3. Models for each dependent variable.

\begin{tabular}{|c|c|c|}
\hline Dependent variable & Models & Description \\
\hline DivTotal & Model 1 & General level of disclosure considering all categories of information analyzed \\
\hline DivAM & Model 2 & Disclosure level of marketing asset information \\
\hline DivIM & Model 3 & Level of disclosure of marketing investment information \\
\hline DivRFE & * & $\begin{array}{l}\text { Level of disclosure of information on changes in financial and economic earnings from marketing } \\
\text { investments }\end{array}$ \\
\hline DivFRFE & Model 4 & $\begin{array}{l}\text { Level of information disclosure of expected future effects on economic and financial earnings and } \\
\text { maintenance of long-term marketing strategies }\end{array}$ \\
\hline DivQL & Model 5 & Disclosure level of qualitative information on marketing investments \\
\hline DivQT & Model 6 & Disclosure level of quantitative information on marketing investments \\
\hline
\end{tabular}

Note. ${ }^{*}$ There is no proposed model for the DivRFE variable because we did not find disclosure in this category in any company in the sample.

\section{Measurement of the marketing investment intensity and the life cycle}

The predictive variables of the study are the marketing investment intensity and the life cycle of the firm. In the international literature, the marketing investment intensity is an index measured through a proxy that uses sales, general, and administrative expenses, deducted from $R \& D$ expenses, weighting by total assets (Luo, 2008; Mizik, 2010). The higher the index of the marketing investment intensity, the greater the volume of the budget dedicated to the marketing department, indicating whether the firm's investment strategy has a strong or weak link with marketing actions (Bae et al., 2017).
Brazilian accounting standards do not require specific disclosure of annual $\mathrm{R} \& \mathrm{D}$ expenditures and most Brazilian companies exercise their right not to disclose this information. Although this information exists in a few companies in the sample, to standardize the methodological procedures, we chose not to deduct the expenses with R\&D. This limitation justifies the operationalization of the proxy for the marketing investment intensity in this study, carried out by weighting selling, general, and administrative expenses for the period by total assets.

To identify the life cycle phases, we used the signals from operating cash flows (FCO), financing cash flows (FCF), and investment cash flows (FCI). Cash flows make it possible to differentiate organizational life cycles because 
they capture differences in firms' profitability, growth, and risk (Cantrell \& Dickinson, 2020). Based on the methodology suggested by Dickinson (2011), the different stages of the life cycle are: birth, if $\mathrm{FCO}<0, \mathrm{FCI}<0$, and $\mathrm{FCF}>0$; growth, if $\mathrm{FCO}>0, \mathrm{FCI}<0$, and $\mathrm{FCF}>0$; maturity, if $\mathrm{FCO}>0, \mathrm{FCI}<0$, and $\mathrm{FCF}<0$; decline, if $\mathrm{FCO}<0, \mathrm{FCI}>0$, and $\mathrm{FCF} \leq$ or $\geq 0$; and the other companies were classified in the turbulence phase.

We aggregated the stages of birth with that of growth (initial stages) and the stages of turbulence with the stage of decline (final stages) so that, together with the stage of maturity, we build a variable with three categories of the life cycle. The previous literature used this procedure (Habib \& Hassan, 2019; Mikosz et al., 2019). The reason for the aggregation is that the uncertainty generated by the information asymmetry of the first two phases is different from the fundamentals of the uncertainty of the last two stages (Habib \& Hassan, 2019). The phases of birth and growth share the condition of dependence on foreign capital and high indebtedness to take advantage of business and growth opportunities (Kabir et al., 2020). The uncertainty of the turbulence and decline phases is generated especially by the volatility in operating results and present cash flows, undermining growth opportunities and decreasing the capacity to recognize the organization's continuity premise (Costa et al., 2017; Krishnan et al., 2021). For additional tests to check the results, we performed new analyses of the effects of the life cycle, also considering the five phases of the life cycle separately.

The estimation model contains covariables to control the effects that other elements generate on voluntary disclosure decisions. These covariables are: (a) corporate governance segment, considering that transparency is one of the requirements for a company to be listed in the highest segments of the levels of governance; (b) industry, segregating cyclical and non-cyclical consumption companies because they are exposed to different risks due to the influences of the economic expansion and retraction cycles; (c) auditing, due to the fact that the Big Four companies have more independence regarding voluntary disclosure recommendations compared to smaller audit companies; (d) ROE, representing the measure of profitability whose variability can arouse different interests of investors for information; (e) institutional control, considering that institutional investors can access privileged information or have greater ability to interpret the information; (f) liquidity, which signals to the market the management of short-term obligations; ( $\mathrm{g}$ ) solvency, which signals to the market the management of long-term obligations; (h); size, considering that large companies have a greater capacity to bear the costs of voluntary disclosure; (i) age, given that companies that have been publicly traded for longer have had more opportunities to define the content of the information disclosed; ( $j$ ) marketto-book, because of the effect of the company's market value on investors' curiosity; and (k) sales growth, because of the effects of monitoring by competing companies. All variables went through the winsorization procedure at the $2.5 \%$ level to avoid problems with outliers (Mizik, 2010). Table 4 shows the operationalization and the source of data for the variables used in this work.

Table 4. Operationalization of variables.

\begin{tabular}{|c|c|c|c|}
\hline Variable & Measures & Data & Authors \\
\hline $\begin{array}{l}\text { Level of } \\
\text { marketing } \\
\text { investment } \\
\text { disclosure }\end{array}$ & $\begin{array}{l}1 \text { when there is information disclosure } \\
\text { and } 0 \text { for the absence of information. } \\
\text { Calculation of the proportion of the } \\
\text { information disclosed in relation to } \\
\text { the expected information. Information } \\
\text { separated into six categories (Appendix A). }\end{array}$ & $\begin{array}{l}\text { Categories: CPC } 00 \text { (2011), CPC } 26 \text { (2011), } \\
\text { Publishes Discussion Paper on Management } \\
\text { Commentary (2005), and Principles } \\
\text { for Ongoing Disclosure and Material } \\
\text { Development Reporting by Listed Entities } \\
\text { (2002); information obtained from B3. }\end{array}$ & Developed in this study. \\
\hline $\begin{array}{l}\text { Marketing } \\
\text { investment } \\
\text { intensity }\end{array}$ & $\begin{array}{l}\text { Selling, general, and administrative } \\
\text { expenses in the period divided by total } \\
\text { assets. }\end{array}$ & Economatica & Luo (2008); Mizik (2010) \\
\hline Life cycle & $\begin{array}{l}1 \text { if the firm is in the early stages (birth and } \\
\text { growth), } 2 \text { for maturity, and } 3 \text { for the final } \\
\text { stages (turbulence and decline). }\end{array}$ & Economatica & Dickinson (2011) \\
\hline $\begin{array}{l}\text { Corporate } \\
\text { governance } \\
\text { segment }\end{array}$ & 1 for New Market and 0 for other segments. & Economatica & Kabir et al. (2020) \\
\hline
\end{tabular}


Table 4. Operationalization of variables (Continued).

\begin{tabular}{|c|c|c|c|}
\hline Variable & Measures & Data & Authors \\
\hline Industry & $\begin{array}{l}1 \text { for cyclic consumption and } 0 \text { for non- } \\
\text { cyclic consumption. }\end{array}$ & B3 & Cantrell and Dickinson (2020) \\
\hline Audit & $\begin{array}{l}1 \text { for Big Four auditing and } 0 \text { for other } \\
\text { auditing companies. }\end{array}$ & B3 & Shi et al. (2021) \\
\hline $\begin{array}{l}\text { Return on equity } \\
\text { (ROE) }\end{array}$ & $\begin{array}{l}\text { Net income divided by shareholders' } \\
\text { equity. }\end{array}$ & Economatica & Ma et al. (2017); Simpson (2008) \\
\hline $\begin{array}{l}\text { Institutional } \\
\text { control }\end{array}$ & $\begin{array}{l}1 \text { for control by institutional investor and } \\
0 \text { for control by non-institutional investor. }\end{array}$ & B3 & $\begin{array}{l}\text { Kabir et al. (2020); Mohamed and } \\
\text { Schwienbacher (2016) }\end{array}$ \\
\hline Liquidity & Current assets divided by current liabilities. & Economatica & Mohamed and Schwienbacher (2016) \\
\hline General solvency & Total assets divided by payable liabilities. & Economatica & $\begin{array}{l}\text { Simpson (2008); Costa, Macedo, } \\
\text { Yokoyama and Almeida (2017) }\end{array}$ \\
\hline Size & Natural logarithm of total assets. & Economatica & $\begin{array}{l}\text { Costa et al. (2017); Kabir et al. (2020); Koo } \\
\text { e Lee (2018); Simpson (2008) }\end{array}$ \\
\hline Age & $\begin{array}{l}\text { Full years since the date of registration of } \\
\text { the firm with the CVM. }\end{array}$ & GetDFPData Web & Bae et al. (2017); Ma et al. (2017) \\
\hline Market-to-book & $\begin{array}{l}\text { Market value of the firm divided by } \\
\text { shareholders' equity. }\end{array}$ & Economatica & $\begin{array}{l}\text { Costa et al. (2017); Kabir et al. (2020); Koo } \\
\text { e Lee (2018) }\end{array}$ \\
\hline Sales growth & $\begin{array}{l}\text { Percentage change in revenues for year } t \text { in } \\
\text { relation to } t-1 \text {. }\end{array}$ & Economatica & Costa et al. (2017); Ma et al. (2017) \\
\hline
\end{tabular}

\section{Regression model equations}

Hypotheses 1 and 2 of the theoretical model were tested using Equation 1, and Hypothesis 3 was tested using Equation 2:

MKTDISC $_{i}=\beta_{0}+\beta_{1}$ MKTINV $_{i}+\beta_{2}$ LIFE_CICLE $_{i}+$ CONTROLS $+\varepsilon$

MKTDISC $_{i}=\beta_{0}+\beta_{1}$ MKTINV $_{i}+\beta_{2}$ LIFE_CICLE $_{i}+\beta_{3}$ MKTINV $i *$ LIFE_CICLE $_{i}+$ CONTROLS $+\varepsilon$

Equation 1 shows the direct relationship between the marketing investment intensity $\left(M K T I N V_{i}\right)$ and the firm's life cycle (LIFE_CICLE $)_{i}$ ) at the level of marketing investment disclosure $\left(M K T D I S C_{i}\right)$. Equation 2 tests the effect of the predictor variable $\left(M K T I N V_{i}\right)$ moderated by the life cycle effect $\left(L I F E_{-} C I C L E_{i}\right)$ on the disclosure level of marketing investments (MKTDISC $C_{i}$ ). Both equations represent multiple linear regression tests with robust standard errors, using each of the six dependent variables proposed in this study (shown in Table 3).

\section{RESULTS}

The analysis of the different categories of marketing information indicates that, on average, voluntary disclosures made by companies are higher for marketing assets (50\%) and types of marketing investments (43\%), while information on the expectations of new investments or future results linked to marketing is minimal $(8 \%$, see Table 5).

To compare the level of marketing investment disclosure between the different information categories, we applied a $t$-test of the difference of means for paired samples (Table 6). The results indicate (a) that the disclosure of marketing assets is greater than the disclosure of future investments and long-term economic and financial results $(t=10.03, p<0.01)$; (b) that the marketing investment disclosure is greater than the disclosure of future investments and long-term economic and financial results $(t=9.98, p<$ 0.01 ); and (c) that the disclosure of qualitative information is greater than the disclosure of quantitative marketing information $(t=9.34, p<0.01)$. 
Table 5. Descriptive statistics and correlation matrix.

\begin{tabular}{|c|c|c|c|c|c|c|c|c|c|c|c|c|c|c|c|c|c|c|c|}
\hline & Variables & 1 & 2 & 3 & 4 & 5 & 6 & 7 & 8 & 9 & 10 & 11 & 12 & 13 & 14 & 15 & 16 & 17 & 18 \\
\hline 1 & DivTotal & 1 & & & & & & & & & & & & & & & & & \\
\hline 2 & DivAM & $0.73^{* * *}$ & 1 & & & & & & & & & & & & & & & & \\
\hline 3 & DivIM & $0.75^{* * *}$ & 0.19 & 1 & & & & & & & & & & & & & & & \\
\hline 4 & DivFRFE & $0.55^{* * *}$ & 0.13 & $0.32^{* *}$ & 1 & & & & & & & & & & & & & & \\
\hline 5 & DivQL & $0.93^{* * *}$ & $0.70^{* * *}$ & $0.60^{* * *}$ & $0.64^{* * *}$ & 1 & & & & & & & & & & & & & \\
\hline 6 & DivQT & $0.88^{* * *}$ & $0.60^{* * *}$ & $0.81^{* * *}$ & $0.30^{* *}$ & $0.65^{* * *}$ & 1 & & & & & & & & & & & & \\
\hline 7 & $\begin{array}{l}\text { Marketing } \\
\text { Int. }\end{array}$ & $0.46^{* * *}$ & $0.39^{* * *}$ & $0.26^{*}$ & $0.29^{* *}$ & $0.49^{* * *}$ & $0.35^{* * *}$ & 1 & & & & & & & & & & & \\
\hline 8 & $\begin{array}{l}\text { Corp. Gov. } \\
\text { Seg. }\end{array}$ & $0.25^{*}$ & 0.04 & $0.37^{* * *}$ & 0.11 & 0.11 & $0.38^{* * *}$ & -0.16 & 1 & & & & & & & & & & \\
\hline 9 & Industry & 0.04 & 0.02 & 0.10 & -0.07 & -0.01 & 0.12 & -0.00 & -0.06 & 1 & & & & & & & & & \\
\hline 10 & Audit & $0.34^{* *}$ & $0.27^{* *}$ & $0.23^{*}$ & 0.19 & $0.26^{*}$ & $0.37^{* * *}$ & 0.13 & $0.47^{* * *}$ & 0.05 & 1 & & & & & & & & \\
\hline 11 & ROE & 0.03 & 0.16 & -0.10 & -0.01 & 0.05 & -0.00 & 0.01 & 0.04 & -0.01 & 0.19 & 1 & & & & & & & \\
\hline 12 & $\begin{array}{l}\text { Instit. } \\
\text { control }\end{array}$ & -0.11 & -0.12 & -0.09 & -0.01 & -0.08 & -0.15 & -0.20 & -0.07 & -0.20 & -0.02 & 0.04 & 1 & & & & & & \\
\hline 13 & Liquidity & -0.04 & -0.13 & 0.05 & 0.09 & -0.07 & 0.01 & -0.15 & 0.19 & 0.17 & 0.12 & 0.04 & 0.05 & 1 & & & & & \\
\hline 14 & $\begin{array}{l}\text { General } \\
\text { solvency }\end{array}$ & 0.04 & -0.05 & 0.08 & 0.15 & -0.00 & 0.09 & -0.06 & 0.13 & 0.16 & 0.09 & 0.08 & -0.00 & $0.89^{* * *}$ & 1 & & & & \\
\hline 15 & Size & $0.23^{*}$ & $0.25^{*}$ & 0.13 & 0.04 & 0.17 & $0.25^{*}$ & -0.10 & $0.43^{* * *}$ & $-0.25^{*}$ & $0.52^{* * *}$ & 0.04 & 0.20 & -0.02 & -0.11 & 1 & & & \\
\hline 16 & Age & -0.16 & 0.02 & $-0.26^{*}$ & -0.09 & -0.07 & $-0.23^{*}$ & 0.14 & $-0.79^{* * *}$ & $0.21^{*}$ & $-0.42^{* * *}$ & -0.06 & 0.01 & -0.10 & -0.09 & $-0.40^{* * *}$ & 1 & & \\
\hline 17 & $\begin{array}{l}\text { Market-to- } \\
\text { book }\end{array}$ & $0.33^{* *}$ & $0.26^{*}$ & $0.25^{*}$ & 0.11 & $0.32^{* *}$ & $0.27^{* *}$ & $0.35^{* * *}$ & 0.20 & 0.02 & $0.34^{* *}$ & -0.10 & -0.13 & -0.00 & -0.01 & $0.31^{* *}$ & -0.20 & 1 & \\
\hline 18 & Sales growth & 0.12 & 0.08 & 0.06 & 0.12 & 0.11 & 0.11 & -0.02 & $0.23^{*}$ & -0.19 & 0.08 & -0.01 & -0.00 & -0.13 & -0.14 & $0.32^{* *}$ & -0.19 & 0.19 & 1 \\
\hline & $\mathrm{N}$ & 89 & 89 & 89 & 89 & 89 & 89 & 89 & 89 & 89 & 89 & 89 & 89 & 89 & 89 & 89 & 89 & 89 & 89 \\
\hline & Mean & 0.25 & 0.50 & 0.43 & 0.08 & 0.36 & 0.18 & 0.17 & 0.63 & 0.79 & 0.57 & 0.01 & 0.44 & 1.89 & 2.10 & 6.34 & 22.46 & 1.84 & 0.04 \\
\hline & $\begin{array}{l}\text { Stand. } \\
\text { deviation }\end{array}$ & 0.16 & 0.37 & 0.34 & 0.20 & 0.23 & 0.13 & 0.14 & 0.49 & 0.41 & 0.50 & 0.43 & 0.50 & 1.70 & 1.83 & 0.73 & 15.67 & 2.14 & 0.31 \\
\hline & Minimum & 0 & 0 & 0 & 0 & 0 & 0 & 0.02 & 0 & 0 & 0 & -1.56 & 0 & 0.04 & 0.34 & 4.66 & 1 & -0.50 & -0.54 \\
\hline & Maximum & 0.58 & 1 & 1 & 0.67 & 0.80 & 0.43 & 0.53 & 1 & 1 & 1 & 0.69 & 1 & 8.05 & 9.49 & 7.72 & 50 & 7.95 & 0.93 \\
\hline
\end{tabular}

Note. ${ }^{* * *}$ sig. $<0.001,{ }^{* *}$ sig. $<0.01,{ }^{*}$ sig. $<0.05$.

Table 6. Results of tests of differences between means of the different categories of marketing information.

\begin{tabular}{cccc}
\hline Comparisons & Difference of means & t-test & p-value \\
\hline DivAM - DivIM & 0.67 & 1.40 & 0.16 \\
DivAM - DivFRFE & 0.42 & 10.03 & 0.00 \\
DivIM - DivFRFE & 0.36 & 9.98 & 0.00 \\
DivQL - DivQT & 0.18 & 9.34 & 0.00 \\
\hline
\end{tabular}

To test Hypothesis 1, the authors used several regression models (see Table 7 - Panel A). Model 1 indicates a positive association between the marketing investment intensity and the general index of the level of total marketing investment disclosure $(\beta=0.47, p<$ $0.001)$. There is also an effect of the marketing investment intensity in the disclosure of marketing assets in Model 2 $(\beta=0.36, p<0.01)$, in marketing investments in Model $3(\beta=0.28, p<0.05)$, qualitative information in Model $5(\beta=0.46, p<0.001)$, and quantitative information in Model $6(\beta=0.40, p<0.001)$. These results support the Hypothesis 1 of this study. 
Table 7. Determinants of the level of marketing investment disclosure.

\begin{tabular}{|c|c|c|c|c|c|c|c|c|c|c|c|c|}
\hline \multicolumn{13}{|c|}{ Panel A: Direct effects } \\
\hline \multirow{3}{*}{ VD } & \multirow{2}{*}{\multicolumn{2}{|c|}{$\begin{array}{l}\text { Model } 1 \\
\text { DivTotal }\end{array}$}} & \multirow{2}{*}{\multicolumn{2}{|c|}{$\begin{array}{c}\text { Model } 2 \\
\text { DivAM }\end{array}$}} & \multirow{2}{*}{\multicolumn{2}{|c|}{$\begin{array}{c}\text { Model } 3 \\
\text { DivIM }\end{array}$}} & \multirow{2}{*}{\multicolumn{2}{|c|}{$\begin{array}{c}\text { Model } 4 \\
\text { DivFRFE }\end{array}$}} & \multirow{2}{*}{\multicolumn{2}{|c|}{$\begin{array}{c}\text { Model } 5 \\
\text { DivQL } \\
\end{array}$}} & \multirow{2}{*}{\multicolumn{2}{|c|}{$\begin{array}{c}\text { Model } 6 \\
\text { DivQT } \\
\end{array}$}} \\
\hline & & & & & & & & & & & & \\
\hline & Beta & $\mathbf{t}$ & Beta & $\mathbf{t}$ & Beta & $\mathbf{t}$ & Beta & $\mathbf{t}$ & Beta & $\mathbf{t}$ & Beta & $\mathbf{t}$ \\
\hline \multicolumn{13}{|l|}{ Predictors } \\
\hline Mkt. Intens. $\left(\mathbf{H}_{1}\right)$ & $0.47^{* * *}$ & 4.67 & $0,36^{* *}$ & 3,12 & $0,28^{*}$ & 2.49 & $0.33^{*}$ & 2.18 & $0.46^{* * *}$ & 4.29 & $0.40^{* * *}$ & 3.89 \\
\hline \multicolumn{13}{|c|}{ Life cycle (birth-growth) $\left(\mathbf{H}_{2}\right)$} \\
\hline (vs.) Maturity & $-0.21^{4}$ & -1.78 & $-0.27^{*}$ & -2.40 & -0.02 & -0.13 & -0.11 & -0.71 & -0.13 & -0.97 & $-0.25^{*}$ & -2.20 \\
\hline (vs.) Turb.-decl. & $-0.25^{*}$ & -2.07 & $-0.23^{*}$ & -1.92 & $-0.21^{\frac{1}{4}}$ & -1.67 & -0.01 & -0.09 & -0.19 & -1.44 & $-0.25^{*}$ & -2.33 \\
\hline \multicolumn{13}{|l|}{ Covariates } \\
\hline Corp. Gov. Seg. & $0.38^{*}$ & 2.28 & 0.15 & 1.04 & 0.44 & 2.59 & $0.15^{*}$ & 0.93 & 0.18 & 1.02 & $0.55^{* *}$ & 3.55 \\
\hline Industry & 0.07 & 0.66 & 0.05 & 0.41 & 0.14 & 1.14 & -0.09 & -0.72 & 0.03 & 0.27 & 0.15 & 1.33 \\
\hline Audit & 0.09 & 0.92 & 0.06 & 0.43 & 0.01 & 0.07 & 0.16 & 1.22 & 0.07 & 0.63 & 0.08 & 0.81 \\
\hline ROE & -0.02 & -0.40 & 0.13 & 1.48 & -0.14 & -1.79 & $-0.07^{\frac{1}{4}}$ & -0.73 & 0.01 & 0.16 & -0.07 & -0.98 \\
\hline Instit. control & 0.04 & 0.36 & -0.04 & -0.44 & 0.06 & 0.56 & 0.07 & 0.54 & 0.04 & 0.33 & 0.01 & 0.11 \\
\hline Liquidity $^{\mathrm{a}}$ & $-0.37^{*}$ & -2.00 & $-0.40^{!}$ & -1.98 & -0.19 & -0.90 & -0.11 & -0.53 & -0.23 & -1.27 & $-0.43^{*}$ & -2.29 \\
\hline General solvency & $0.40^{+}$ & 1.92 & $0.37^{+}$ & 1.78 & 0.22 & 1.08 & 0.27 & 1.05 & 0.24 & 1.15 & $0.46^{*}$ & 2.41 \\
\hline Size & 0.14 & 0.91 & $0.31^{*}$ & 2.22 & -0.04 & -0.30 & -0.05 & -0.26 & 0.10 & 0.60 & 0.17 & 1.21 \\
\hline Age & 0.17 & 0.92 & 0.25 & 1.62 & 0.00 & -0.02 & 0.07 & 0.45 & 0.09 & 0.48 & 0.22 & 1.32 \\
\hline Market-to-book & 0.05 & 0.62 & 0.06 & 0.70 & 0.07 & 0.74 & -0.07 & -0.61 & 0.09 & 0.99 & -0.01 & -0.10 \\
\hline Sales growth & -0.01 & -0.12 & -0.04 & -0.46 & -0.05 & -0.48 & 0.13 & 1.41 & 0.01 & 0.15 & -0.03 & -0.40 \\
\hline Constant & -0.15 & -0.59 & -0.79 & -1.52 & 0.17 & 0.31 & 0.00 & 0.00 & -0.07 & -0.19 & -0.20 & -1.09 \\
\hline $\mathrm{N}$ & 89 & & 89 & & 89 & & 89 & & 89 & & 89 & \\
\hline F-Test & $5.01^{* * *}$ & & $4.76^{* * *}$ & & $3.44^{* * *}$ & & 0.85 & & $4.70^{* * *}$ & & $4.57^{* * *}$ & \\
\hline $\mathrm{R}^{2}$ & 0.43 & & 0.36 & & 0.31 & & 0.18 & & 0.34 & & 0.45 & \\
\hline
\end{tabular}

\section{Panel B: Moderate effects}

\begin{tabular}{|c|c|c|c|c|c|c|c|c|c|c|c|c|}
\hline \multicolumn{13}{|l|}{ Predictors } \\
\hline Mkt. Intens. & -0.06 & -0.19 & 0.14 & 0.45 & -0.18 & -0.68 & -0.14 & -0.62 & -0.15 & -0.50 & 0.04 & 0.16 \\
\hline \multicolumn{13}{|c|}{ Life cycle (birth-growth) } \\
\hline (vs.) Maturity & $-0.45^{*}$ & -2.27 & $-0.37^{+}$ & -1.74 & -0.20 & -0.90 & -0.37 & -1.56 & $-0.49^{*}$ & -2.33 & -0.30 & -1.52 \\
\hline (vs.) Turb.-decl. & $-0.64^{* *}$ & -2.87 & $-0.40^{4}$ & -1.80 & $-0.56^{*}$ & -2.62 & -0.33 & -1.30 & $-0.56^{*}$ & -2.34 & $-0.61^{* *}$ & -3.05 \\
\hline \multicolumn{13}{|l|}{ Interaction } \\
\hline \multicolumn{13}{|c|}{ Mkt. Int. ${ }^{*}$ Life cycle (birth-growth) $\left(\mathbf{H}_{3}\right)$} \\
\hline (vs.) Maturity & 0.45 & 1.58 & 0.19 & 0.63 & 0.36 & 1.31 & 0.46 & 1.65 & $0.64^{*}$ & 2.28 & 0.14 & 0.52 \\
\hline (vs.) Turb.-decl. & $0.61^{*}$ & 2.28 & 0.26 & 0.94 & $0.55^{*}$ & 2.22 & 0.49 & 1.73 & $0.59^{*}$ & 2.23 & $0.55^{*}$ & 2.21 \\
\hline \multicolumn{13}{|l|}{ Covariates } \\
\hline Corp. Gov. Seg. & $0.37^{*}$ & 2.27 & 0.15 & 1.03 & $0.43^{*}$ & 2.56 & 0.14 & 0.91 & 0.17 & 1.01 & $0.54^{* * *}$ & 3.62 \\
\hline Industry & 0.08 & 0.78 & 0.05 & 0.44 & 0.14 & 1.29 & -0.08 & -0.70 & 0.03 & 0.31 & 0.16 & 1.64 \\
\hline Audit & 0.11 & 1.27 & 0.07 & 0.51 & 0.03 & 0.26 & 0.17 & 1.36 & 0.09 & 0.84 & 0.11 & 1.18 \\
\hline ROE & -0.08 & -1.28 & 0.10 & 1.07 & $-0.20^{* *}$ & -2.63 & -0.11 & -1.14 & -0.03 & -0.44 & $-0.14^{*}$ & -2.13 \\
\hline Instit. control & 0.08 & 0.75 & -0.03 & -0.27 & 0.10 & 0.95 & 0.10 & 0.72 & 0.07 & 0.57 & 0.06 & 0.61 \\
\hline Liquidity $^{\mathbf{a}}$ & $-0.44^{*}$ & -2.18 & $-0.43^{*}$ & -2.03 & -0.26 & -1.16 & -0.15 & -0.69 & -0.27 & -1.34 & $-0.53^{* *}$ & -2.75 \\
\hline
\end{tabular}


Table 7. Determinants of the level of marketing investment disclosure (Continued).

\begin{tabular}{|c|c|c|c|c|c|c|c|c|c|c|c|c|}
\hline General solvency & $0.47^{*}$ & 2.15 & $0.40^{+}$ & 1.86 & 0.30 & 1.36 & 0.32 & 1.19 & 0.29 & 1.28 & $0.57^{* *}$ & 2.89 \\
\hline Size & 0.13 & 0.87 & $0.31^{*}$ & 2.19 & -0.06 & -0.37 & -0.06 & -0.30 & 0.10 & 0.60 & 0.15 & 1.11 \\
\hline Age & 0.19 & 1.08 & $0.25^{+}$ & 1.67 & 0.02 & 0.10 & 0.09 & 0.55 & 0.10 & 0.57 & 0.24 & 1.57 \\
\hline Market-to-book & 0.05 & 0.66 & 0.06 & 0.69 & 0.07 & 0.73 & -0.07 & -0.59 & 0.10 & 1.22 & -0.02 & -0.27 \\
\hline Sales growth & -0.06 & -0.68 & -0.06 & -0.71 & -0.09 & -0.89 & 0.09 & 0.90 & -0.03 & -0.39 & -0.08 & -0.93 \\
\hline Constant & -0.06 & -0.24 & -0.70 & -1.31 & 0.34 & 0.65 & 0.10 & 0.31 & 0.07 & 0.18 & -0.15 & -0.82 \\
\hline $\mathrm{N}$ & 89 & & 89 & & 89 & & 89 & & 89 & & 89 & \\
\hline F-test & $5.39^{* * *}$ & & $4.70^{* * *}$ & & $3.51^{* * *}$ & & 0.91 & & $4.79^{* * *}$ & & $5.70^{* * *}$ & \\
\hline $\mathrm{R}^{2}$ & 0.47 & & 0.37 & & 0.35 & & 0.21 & & 0.38 & & 0.51 & \\
\hline
\end{tabular}

Note. ${ }^{* * *}$ sig. $<0.001,{ }^{* *}$ sig. $<0.01,{ }^{*}$ sig. $<0.05,+\frac{1}{t}$ sig. $<0.1$. Robust regression. ${ }^{\mathbf{a}}$ The hypothesis test without the inclusion of the liquidity covariate generated results without significant changes in betas and in the statistical significance of the predictor variables compared to the results in this table, certifying that the correlation between liquidity and general solvency does not cause bias in the estimation of the results.

Panel A in Table 7 shows the relationship of the life cycle phases, grouped into three categories. Companies that are in the birth and growth stages in the life cycle are the reference group in the regression model (intercept). The results indicate that companies in the maturity phase disclose less marketing information to companies that are in the birth and growth phases (Model 1: $\beta=-0.21, p<$ $0.10)$. There is a lower level of disclosure in companies in the maturity phase, compared to firms in the birth and growth phases, considering exclusively the disclosure of marketing asset information (Model 2: $\beta=-0.27, p<0.05$ ) and disclosure of quantitative marketing information (Model 6: $\beta=-0.25, p<0.05$ ).

Firms that are in the turbulent and declining phases also disclose less information compared to firms that are in the birth and growth phases. We found this evidence in Model 1, which uses the general level of information disclosure level $(\beta=-0.25, p<0.05)$; in Model 2, which considers information from marketing assets $(\beta=-0.23$, $p<0.05)$; in Model 3, with information on marketing investments $(\beta=-0.21, p<0.1)$; and in Model 6, which concentrates only information with a quantitative perspective $(\beta=-0.25, p<0.05)$, supporting Hypothesis 2 of this study.

The Hypothesis 3 argues that the greater the marketing investment intensity, the lower (vs. higher) the level of marketing investment disclosure in companies in the birth and growth phases (vs. in the stages of maturity, turbulence, and decline). The results described in Panel B of Table 7 indicate that when the marketing investment intensity increases, companies that are in the maturity phase disclose more qualitative information compared to companies that are in the birth and growth phases $(\beta=0.64, p<0.05)$. The results show that the firms in the turbulence and decline phases disclose more information considering the general index of the level of marketing information disclosure presented in Model $1(\beta=0.61, p<0.05)$, the investment information presented in Model $3(\beta=0.55, p<0.05)$, the qualitative information analyzed using Model $5(\beta=0.59, p<0.05)$ and the quantitative information represented in Model $6(\beta=0.55, p<0.05)$. The set of findings supported Hypothesis 3. We demonstrated the estimated effects in Figure 2.

\section{Tests of additional models (post hoc analysis)}

Studies have pointed out the phases of birth and growth as the stage in which the fear of mimicry of competition may be strongest (Habib \& Hassan, 2019), driving the retention of information more strongly (Dye, 2001) when there is a high level of strategic investments (Bakarich et al., 2019). Therefore, we chose to perform the hypothesis test considering the five phases of the life cycle, with the growth phase being the reference group in the regression model (intercept). Table 8 shows the results, segregated in Panel A, for direct relationships between the marketing investment intensity and the life cycle with the level of marketing investment disclosure, and Panel B, for relationships moderated by the five phases of the life cycle. 


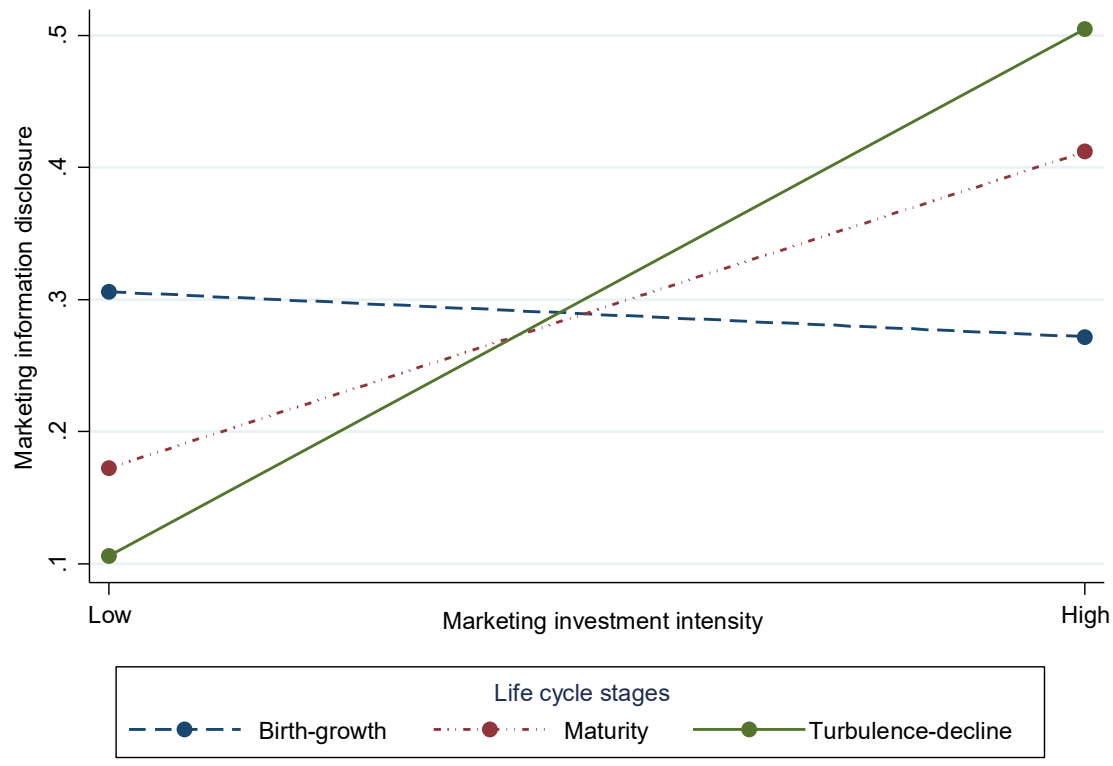

Figure 2. Effects of the marketing investment intensity on the general index of the level of marketing investment disclosure moderated by the life cycle phase of firms.

Table 8. Determinants of the level of marketing investment disclosure considering the five life cycle phases individually.

\begin{tabular}{|c|c|c|c|c|c|c|c|c|c|c|c|c|}
\hline \multicolumn{13}{|c|}{ Panel A: Direct effects } \\
\hline \multirow{3}{*}{ VD } & \multirow{2}{*}{\multicolumn{2}{|c|}{$\begin{array}{l}\text { Model } 1 \\
\text { DivTotal }\end{array}$}} & \multirow{2}{*}{\multicolumn{2}{|c|}{$\begin{array}{l}\text { Model } 2 \\
\text { DivAM }\end{array}$}} & \multirow{2}{*}{\multicolumn{2}{|c|}{$\begin{array}{l}\text { Model } 3 \\
\text { DivIM }\end{array}$}} & \multirow{2}{*}{\multicolumn{2}{|c|}{$\begin{array}{l}\text { Model } 4 \\
\text { DivFRFE }\end{array}$}} & \multirow{2}{*}{\multicolumn{2}{|c|}{$\begin{array}{l}\text { Model } 5 \\
\text { DivQL }\end{array}$}} & \multirow{2}{*}{\multicolumn{2}{|c|}{$\begin{array}{l}\text { Model } 6 \\
\text { DivQT }\end{array}$}} \\
\hline & & & & & & & & & & & & \\
\hline & Beta & $\mathbf{t}$ & Beta & $\mathbf{t}$ & Beta & $\mathbf{t}$ & Beta & $\mathbf{t}$ & Beta & $\mathbf{t}$ & Beta & $\mathbf{t}$ \\
\hline \multicolumn{13}{|l|}{ Predictors } \\
\hline Mkt. Int. $\left(\mathbf{H}_{1}\right)$ & $0.47^{* * *}$ & 4.16 & $0.39^{* *}$ & 3.10 & $0.26^{*}$ & 2.06 & $0.33^{*}$ & 2.15 & $0.46^{* * *}$ & 3.82 & $0.41^{* * *}$ & 3.62 \\
\hline \multicolumn{13}{|c|}{ Life cycle (growth) $\left(\mathbf{H}_{2}\right)$} \\
\hline (vs.) Birth & -0.09 & -0.68 & -0.06 & -0.39 & -0.12 & -0.88 & 0.06 & 0.36 & -0.07 & -0.48 & -0.08 & -0.59 \\
\hline (vs.) Maturity & -0.27 & -1.63 & $-0.32^{*}$ & -2.39 & -0.09 & -0.56 & -0.07 & -0.34 & -0.17 & -1.02 & $-0.30^{*}$ & -2.03 \\
\hline (vs.) Turbulence & $-0.30^{+}$ & -1.87 & $-0.31^{*}$ & -2.32 & -0.24 & -1.52 & 0.03 & 0.17 & -0.22 & -1.38 & $-0.31^{*}$ & -2.14 \\
\hline (vs.) Decline & -0.17 & -1.31 & -0.07 & -0.56 & -0.22 & -1.62 & 0.00 & -0.01 & -0.14 & -1.11 & -0.15 & -1.25 \\
\hline \multicolumn{13}{|l|}{ Covariates } \\
\hline Corp. Gov. Seg. & $0.39^{*}$ & 2.31 & 0.18 & 1.21 & $0.43^{*}$ & 2.47 & 0.14 & 0.87 & 0.18 & 1.04 & $0.56^{* * *}$ & 3.54 \\
\hline Industry & 0.08 & 0.75 & 0.04 & 0.32 & 0.16 & 1.35 & -0.09 & -0.73 & 0.04 & 0.35 & 0.15 & 1.37 \\
\hline Audit & 0.07 & 0.65 & 0.02 & 0.18 & 0.00 & 0.00 & 0.17 & 1.23 & 0.06 & 0.47 & 0.06 & 0.55 \\
\hline ROE & -0.02 & -0.34 & 0.13 & 1.56 & $-0.14^{!}$ & -1.77 & -0.07 & -0.75 & 0.01 & 0.20 & -0.06 & -0.89 \\
\hline Instit. control & 0.04 & 0.40 & -0.04 & -0.41 & 0.07 & 0.64 & 0.07 & 0.51 & 0.04 & 0.36 & 0.02 & 0.15 \\
\hline Liquidity & $-0.37^{\frac{1}{4}}$ & -1.85 & -0.36 & -1.65 & -0.22 & -1.06 & -0.10 & -0.47 & -0.24 & -1.21 & $-0.42^{4}$ & -2.07 \\
\hline General solvency & 0.39 & 1.87 & $0.35^{+}$ & 1.68 & 0.23 & 1.11 & 0.27 & 1.05 & 0.24 & 1.13 & $0.45^{4}$ & 2.31 \\
\hline Size & 0.14 & 0.84 & $0.33^{*}$ & 2.21 & -0.07 & -0.43 & -0.05 & -0.25 & 0.10 & 0.54 & 0.17 & 1.17 \\
\hline Age & 0.16 & 0.86 & 0.24 & 1.53 & -0.01 & -0.07 & 0.08 & 0.49 & 0.08 & 0.45 & 0.21 & 1.24 \\
\hline Market-to-book & 0.08 & 0.83 & 0.08 & 0.87 & 0.10 & 0.90 & -0.09 & -0.69 & 0.11 & 1.10 & 0.01 & 0.12 \\
\hline Sales growth & -0.03 & -0.36 & -0.07 & -0.85 & -0.06 & -0.55 & 0.14 & 1.43 & 0.00 & 0.01 & -0.05 & -0.68 \\
\hline
\end{tabular}


Table 8. Determinants of the level of marketing investment disclosure considering the five life cycle phases individually. (Continued).

\begin{tabular}{|c|c|c|c|c|c|c|c|c|c|c|c|c|}
\hline Constant & -0.12 & -0.46 & -0.81 & -1.45 & 0.29 & 0.51 & -0.02 & -0.07 & -0.04 & -0.10 & -0.19 & -0.95 \\
\hline $\mathrm{N}$ & 89 & & 89 & & 89 & & 89 & & 89 & & 89 & \\
\hline F-test & $4.63^{* * *}$ & & $4.08^{* * *}$ & & $3.33^{* * *}$ & & 0.76 & & $4.90^{* * *}$ & & $3.85^{* * *}$ & \\
\hline $\mathrm{R}^{2}$ & 0.43 & & 0.38 & & 0.32 & & 0.18 & & 0.34 & & 0.45 & \\
\hline \multicolumn{13}{|c|}{ Panel B: Moderate effects } \\
\hline \multicolumn{13}{|l|}{ Predictors } \\
\hline Mkt. Intens. & -0.27 & -0.78 & -0.04 & -0.14 & -0.33 & -0.96 & -0.20 & -0.59 & -0.28 & -0.82 & -0.22 & -0.78 \\
\hline \multicolumn{13}{|l|}{ Life cycle (growth) } \\
\hline (vs.) Birth & -0.28 & -1.34 & -0.23 & -1.00 & -0.24 & -1.11 & -0.04 & -0.14 & -0.20 & -0.83 & -0.33 & -1.82 \\
\hline (vs.) Maturity & $-0.66^{*}$ & -2.63 & $-0.55^{*}$ & -2.48 & -0.39 & -1.34 & -0.38 & -1.13 & $-0.64^{*}$ & -2.49 & $-0.53^{*}$ & -2.41 \\
\hline (vs.) Turbulence & $-0.76^{* *}$ & -2.85 & $-0.53^{*}$ & -2.42 & $-0.63^{*}$ & -2.39 & -0.35 & -1.13 & $-0.63^{*}$ & -2.31 & $-0.77^{* * *}$ & -3.47 \\
\hline (vs.) Decline & $-0.56^{* *}$ & -3.10 & $-0.37^{*}$ & -2.10 & $-0.56^{* *}$ & -2.89 & -0.12 & -0.49 & $-0.48^{*}$ & -2.52 & $-0.54^{* * *}$ & -3.57 \\
\hline \multicolumn{13}{|l|}{ Interaction } \\
\hline \multicolumn{13}{|c|}{ Mkt. Int. ${ }^{*}$ Life cycle (growth) $\left(\mathbf{H}_{3}\right)$} \\
\hline (vs.) Birth & 0.17 & 0.84 & 0.17 & 0.78 & 0.09 & 0.51 & 0.08 & 0.40 & 0.09 & 0.44 & 0.25 & 1.46 \\
\hline (vs.) Maturity & $0.66^{+}$ & 1.95 & 0.38 & 1.35 & 0.49 & 1.39 & 0.53 & 1.37 & $0.77^{*}$ & 2.26 & 0.42 & 1.46 \\
\hline (vs.) Turbulence & $0.72^{*}$ & 2.47 & 0.36 & 1.45 & $0.59^{+}$ & 1.96 & 0.58 & 1.64 & $0.64^{*}$ & 2.19 & $0.71^{* *}$ & 2.89 \\
\hline (vs.) Decline & $0.43^{* *}$ & 3.08 & $0.35^{* *}$ & 3.07 & $0.37^{*}$ & 2.29 & 0.06 & 0.41 & $0.36^{*}$ & 2.34 & $0.43^{* * *}$ & 3.86 \\
\hline \multicolumn{13}{|l|}{ Covariates } \\
\hline Corp. Gov. Seg. & $0.39^{*}$ & 2.33 & 0.18 & 1.21 & $0.43^{*}$ & 2.45 & 0.15 & 0.93 & 0.19 & 1.04 & $0.57^{* * *}$ & 3.67 \\
\hline Industry & 0.11 & 1.09 & 0.07 & 0.60 & 0.19 & 1.62 & -0.10 & -0.80 & 0.06 & 0.54 & $0.19^{4}$ & 1.97 \\
\hline Audit & 0.08 & 0.83 & 0.03 & 0.19 & 0.01 & 0.08 & 0.20 & 1.48 & 0.07 & 0.56 & 0.09 & 0.84 \\
\hline $\mathrm{ROE}$ & -0.07 & -1.03 & 0.11 & 1.11 & $-0.20^{*}$ & -2.42 & -0.10 & -1.05 & -0.03 & -0.34 & $-0.12^{!}$ & -1.82 \\
\hline Instit. control & 0.10 & 0.95 & 0.00 & 0.04 & 0.13 & 1.18 & 0.08 & 0.57 & 0.09 & 0.71 & 0.09 & 0.86 \\
\hline Liquidity & $-0.50^{*}$ & -2.25 & $-0.49^{*}$ & -2.09 & -0.35 & -1.49 & -0.07 & -0.29 & -0.32 & -1.42 & $-0.58^{* *}$ & -2.79 \\
\hline General solvency & $0.53^{*}$ & 2.26 & $0.47^{*}$ & 2.12 & 0.36 & 1.56 & 0.25 & 0.86 & 0.33 & 1.37 & $0.62^{* *}$ & 3.01 \\
\hline Size & 0.15 & 0.89 & $0.35^{*}$ & 2.33 & -0.06 & -0.37 & -0.07 & -0.38 & 0.10 & 0.58 & 0.18 & 1.26 \\
\hline Age & 0.16 & 0.93 & 0.22 & 1.43 & -0.01 & -0.06 & 0.12 & 0.78 & 0.08 & 0.46 & 0.22 & 1.40 \\
\hline Market-to-book & 0.08 & 0.78 & 0.08 & 0.78 & 0.11 & 0.87 & -0.10 & -0.74 & 0.13 & 1.22 & -0.01 & -0.11 \\
\hline Sales growth & -0.08 & -0.87 & -0.08 & -0.91 & -0.10 & -0.95 & 0.08 & 0.79 & -0.05 & -0.52 & -0.10 & -1.14 \\
\hline Constant & -0.02 & -0.09 & -0.74 & -1.28 & 0.47 & 0.80 & 0.13 & 0.43 & 0.12 & 0.29 & -0.13 & -0.68 \\
\hline $\mathrm{N}$ & 89 & & 89 & & 89 & & 89 & & 89 & & 89 & \\
\hline F-test & $4.78^{* * *}$ & & $5.54^{* * *}$ & & $3.54^{* * *}$ & & 0.78 & & $4.56^{* * *}$ & & $5.40^{* * *}$ & \\
\hline $\mathrm{R}^{2}$ & 0.50 & & 0.41 & & 0.37 & & 0.22 & & 0.40 & & 0.54 & \\
\hline
\end{tabular}

Note. ${ }^{* * *}$ sig. $<0.001,{ }^{* *}$ sig. $<0.01,{ }^{*}$ sig. $<0.05,+\frac{1}{4}$ sig. $<0.1$. Robust regression.

The results show a positive relationship between marketing investment intensity and the level of marketing investment disclosure in all models, except Model 4. Regarding the effects of the life cycle, we found that the level of marketing investment disclosure is lower in companies in the maturity and turbulence phases compared to the growth phase. Such results are similar to the analyses presented in Panel A of Table 7, supporting the hypothesis.
The effects of marketing intensity on the level of marketing investment disclosure, moderated by the stages of the life cycle, are in Panel B of Table 8. The results indicate that the greater the marketing investment intensity, the more firms that are in the phases of maturity, turbulence, and decline disseminate marketing information, once again supporting the Hypothesis 3. 


\section{CONCLUSIONS}

We found that the marketing investment intensity positively influences the level of marketing investment disclosure in all informational perspectives evaluated by this study. Therefore, there is evidence that firms expand the marketing investment disclosure to differentiate themselves from competing companies (Shi et al., 2021) when they use high volumes of resources in marketing investments. This behavior is in line with the theoretical arguments that companies that employ high volumes of marketing investments draw attention from the financial market and that, therefore, investors charge for a higher level of transparency and publication (Sidhu \& Roberts, 2008; Stewart, 2009).

The effort to perform signage to the market shows that companies use marketing disclosure as a differentiation strategy and believe that stakeholders recognize high marketing investments as positive strategies (Bae et al., 2017; Ma et al., 2017). Voluntary disclosure theory suggests that voluntary disclosure is carried out because there is a minimization of information asymmetry between economic agents (Kabir et al., 2020), greater transparency of firms (Dye, 2001) and the establishment of a relationship of trust with investors, allowing to reduce the cost of capital (Jensen \& Meckling, 1976).

The results demonstrate that companies in the stages of birth and growth perform higher levels of disclosure than the other stages. These firms face strong competition not only in the product market but also in the financial market due to the search for investors (Cantrell \& Dickinson, 2020). As companies in the birth and growth phases are still in the process of consolidation, there is a high demand for external financing (Habib \& Hassan, 2019). Because of this, companies in the birth and growth stages can manipulate voluntary disclosures (Khurana et al., 2006) as a resource to differentiate themselves (Jensen \& Meckling, 1976).

The findings show that firms in the birth and growth stages prioritize the disclosure of information about marketing assets and information with a quantitative nature. These characteristics reinforce the theoretical arguments that firms at these stages in the life cycle recognize the importance (a) of justifying how they are developing the marketing assets that drive the company's market value (Markovitch et al., 2020; Srivastava et al., 1998) and (b) to perform accountability by informing quantitative data that can be incorporated into valuation analyses carried out by investors (Edeling et al., 2020; Sydney-Hilton \& Vila-Lopez, 2019).

The results also demonstrate that the positive effect of the high marketing investment intensity on the level of marketing investment disclosure changes to negative when firms are in the phases of birth and growth. This moderating effect occurs more widely, especially for information of a qualitative nature, that is, which presents descriptively what are the investments and expectations of marketing strategies. This shows that companies in the birth and growth phases, when allocating high budgets for marketing investments, prefer to keep this information hidden, indicating that protection against competitors is more important (Mohamed \& Schwienbacher, 2016) than the establishment of transparency toward the financial market to decrease capital costs (Dye, 2001; Verrecchia, 2001). The results converge with the literature that indicated that companies in the birth and growth phases can 'overshadow' information, providing a more ambiguous communication when they are in potentially more volatile or uncertain business environments (Bakarich et al., 2019).

The low level of disclosure when there are high marketing investments is the result of uncertainties regarding the ability of start-ups to establish themselves in the market and reach the maturity stage (Krishnan et al., 2021), which makes the marketing investment disclosure more costly to companies that are in other stages of the life cycle (Khurana et al., 2006). There is also the risk that the disclosure will become a negative event in the face of the loss of the credibility of this information on a subsequent date when more information on the company's performance becomes public if it is not compatible with the expectations created by the market from the previously disclosed information. (Verrecchia, 2001). With this, the status of a resource for differentiating marketing information, when there is a high investment intensity, changes to the status of secrecy in companies that are in the stages of birth and growth of the life cycle.

The companies that are in the birth and growth phases are no different from the companies in the maturity phase. However, when compared only with the companies in the turbulence and decline phases of the life cycle, they present less disclosure of information in several aspects (types of investments and qualitative and quantitative information). Firms that are in turbulence and decline are underperforming, which can boost the marketing investment disclosure to show the financial market their actions in search of restoring the balance of their results (Mikosz et al., 2019). In addition, companies that are in turbulence and decline generally do not attract the attention of competitors, making voluntary disclosure capture more benefits and less costly because of competitors mimicry practices (Habib \& Hassan, 2019).

The results of this study offer advances to the literature on the marketing-finance interface by presenting evidence that converges with the theoretical argument that the marketing investment disclosure is manipulated to justify marketing investments, signal the fundamentals of these 
strategies, and reduce the asymmetry of information between companies and the financial market (Ma et al., 2017; Kabir et al., 2020). The main contribution of the study to the field of marketing was to demonstrate that the realization of high marketing investments in companies that are in the stages of birth and growth assumes a character of private information or business secret, but that this condition of secrecy becomes differentiation feature when the firm reaches the maturity stage, especially for qualitative information.

\section{Limitations and future research}

A limitation of this study refers to the analysis of the life cycle phases using a multi-categorical variable that requires using a reference group in the regression model, making it difficult to compare the effects between the other life cycle phases. Future studies can overcome this limitation using subsamples for further analysis. Second, the present study is limited in terms of the sample size, as it considers only Brazilian companies listed in B3 belonging to sectors related to consumption. Such a limitation can be removed by future

\section{REFERENCES}

Bae, J., Kim, S. J., \& Oh, H. (2017). Taming polysemous signals: The role of marketing intensity on the relationship between financial leverage and firm performance. Review of Financial Economics, 33, 29-40. https://doi.org/10.1016/j.rfe.2016.12.002

Bakarich, K. M., Hossain, M., \& Weintrop, J. (2019). Different time, different tone: Company life cycle. Journal of Contemporary Accounting \& Economics, 15(1), 69-86. https://doi.org/10.1016/j.jcae.2018.12.002

Bardin, L. (1977). Análise de conteúdo. Lisboa: Ediçôes 70.

Bayer, E., Tuli, K. R., \& Skiera, B. (2017). Do disclosures of customer metrics lower investors' and analysts' uncertainty but hurt firm performance? Journal of Marketing Research, 54(2), 239-259. https://doi.org/10.1509\%2Fjmr.14.0028 studies by expanding analyses with data from companies in other countries (e.g., Nasdaq, Nikkei, DowJones). Third, the absence of exclusive data on marketing expenses forced us to use a proxy based on administrative, general, and sales expenses, as already practiced in international literature. In addition to this limitation, the measurement of the marketing investment intensity in this study has undergone adaptation, considering the methodology used in international studies, as it is not common for Brazilian companies to disclose the amount of $\mathrm{R} \& \mathrm{D}$ expenditures. Finally, there is a limitation regarding the collection of data on voluntary disclosure of information. This collection, because it is manual and depends on the interpretation of the context of the information, made the extension of such activity unfeasible to form a data panel, with information within a timeframe. We suggest that future research should investigate the relationship between the marketing investment disclosure and the market value of firms and the performance of shares, in the short and long term, controlling the effects of the level of marketing investment and the phases of the marketing life cycle.
Cantrell, B. W., \& Dickinson, V. (2020). Conditional life cycle: An examination of operating performance for leaders and laggards. Management Science, 66(1), 433-451. https://doi.org/10.1287/mnsc.2018.3209

Costa, W. B. D., Macedo, M. A. D. S., Yokoyama, K. Y., \& Almeida, J. E. F. D. (2017). Análise dos estágios de ciclo de vida de companhias abertas no Brasil: Um estudo com base em variáveis contábilfinanceiras. Brazilian Business Review, 14(3), 304-320. https://doi.org/10.15728/bbr.2017.14.3.3

Dickinson, V. (2011). Cash flow patterns as a proxy for firm life cycle. The Accounting Review, 86(6), 1969-1994. https://doi.org/10.2308/accr-10130 
Dye, R. A. (2001). An evaluation of "essays on disclosure" and the disclosure literature in accounting. Journal of Accounting and Economics, 32(1-3), 181-235. https://doi.org/10.1016/S0165-4101(01)00024-6

Edeling, A., Srinivasan, S., \& Hanssens, D. M. (2020). The marketing-finance interface: A new integrative review of metrics, methods, and findings and an agenda for future research. International Journal of Research in Marketing. (in press). https://doi.org/10.1016/j.ijresmar.2020.09.005

Fine, M. B., Gleason, K., \& Mullen, M. (2017). Marketing spending and aftermarket performance of IPO firms. Marketing Intelligence \& Planning, 35(4), 560-576. http://dx.doi.org/10.1108/MIP-05-2016-0083

Habib, A., \& Hasan, M. M. (2019). Corporate life cycle research in accounting, finance and corporate governance: A survey, and directions for future research. International Review of Financial Analysis, 61, 188-201. https://doi.org/10.1016/j.irfa.2018.12.004

Jensen, M. C., \& Meckling, W. H. (1976). Theory of the firm: Managerial behavior, agency costs and ownership structure. Journal of Financial Economics, 3(4), 305-360. https://doi.org/10.1016/0304-405X(76)90026-X

Joshi, A., \& Hanssens, D. M. (2010). The direct and indirect effects of advertising spending on firm value. Journal of Marketing, 74(1), 20-33. https://doi.org/10.1509\%2Fjmkg.74.1.20

Kabir, H., Su, L., \& Rahman, A. (2020). Firm life cycle and the disclosure of estimates and judgments in goodwill impairment tests: Evidence from Australia. Journal of Contemporary Accounting \& Economics, 16(3), 100207. https://doi.org/10.1016/j.jcae.2020.100207

Khurana, I. K., Pereira, R., \& Martin, X. (2006). Firm growth and disclosure: An empirical analysis. Journal of Financial and Quantitative Analysis, 41(2), 357-380. Retrieved from https://www.jstor.org/stable/27647251

Koo, D. S., \& Lee, D. (2018). Influential chief marketing officers and management revenue forecasts. The Accounting Review, 93(4), 253-281. http://dx.doi.org/10.2308/accr-51946

Krishnan, G. V., Myllymäki, E. R., \& Nagar, N. (2021). Does financial reporting quality vary across firm life cycle? Journal of Business Finance \& Accounting, 48(5-6), 954987. https://doi.org/10.1111/jbfa. 12508

Luo, X. (2008). When marketing strategy first meets Wall Street: Marketing spendings and firms' initial public offerings. Journal of Marketing, 72(5), 98-109. http://dx.doi.org/10.1509/jmkg.72.5.098

Ma, M., Dewally, M., \& Huang, J. (2017). Marketing strategy after meeting Wall Street: The role of information asymmetry. Journal of Financial Research, 40(3), 369-400. http://dx.doi.org/10.1111/jifir.12128

Markovitch, D. G., Huang, D., \& Ye, P. (2020). Marketing intensity and firm performance: Contrasting the insights based on actual marketing expenditure and its SG\&A proxy. Journal of Business Research, 118, 223-239. https://doi.org/10.1016/j.jbusres.2020.06.032
McIlkenny, P., \& Persaud, A. (2017). Value relevance of the voluntary disclosureofadvertisingexpenditure:Evidencefrom Canada. International Journal of Accounting and Finance, 7(3), 185208. http://dx.doi.org/10.1504/IJAF.2017.088027

Mikosz, K. S. C., Roma, C. M. S., Louzada, L. C., \& Macedo, M. R. G. O. (2019). Previsão de retornos e preços das açôes a partir de dados contábeis condicionado ao ciclo de vida das firmas. Revista de Contabilidade e Organizaçôes, 13, e160869. http://dx.doi.org/10.11606/issn.1982-6486. $\underline{\text { rco.2019.160869 }}$

Mizik, N. (2010). The theory and practice of myopic management. Journal of Marketing Research, 47(4), 594-611. https://doi.org/10.1509\%2Fjmkr.47.4.594

Mohamed, A., \& Schwienbacher, A. (2016). Voluntary disclosure of corporate venture capital investments. Journal of Banking \& Finance, 68(July), 69-83. https://doi.org/10.1016/j.jbankfin.2016.03.001

Oh, Y. K., Gulen, H., Kim, J. M., \& Robinson, W. T. (2016). Do stock prices undervalue investments in advertising? Marketing Letters, 27(4), 611-626. https://doi.org/10.1007/s11002-016-9411-4

Shi, H., Grewal, R., \& Sridhar, S. (2021). Organizational herding in advertising spending disclosures: Evidence and mechanisms. Journal of Marketing Research, 58(3). https://doi.org/10.1177\%2F0022243720978954

Sidhu, B. K., \& Roberts, J. H. (2008). The marketing accounting interface-lessons and limitations. Journal of Marketing Management, 24(7-8), 669-686. http://dx.doi.org/10.1362/026725708X345461

Silveira, C. S., Oliveira, M. O. R. de, Heldt, R., \& Luce, F. B. (2020). Trade-off between value creation and value appropriation? Marketing Intelligence \& Planning, 39(1), 1-16. https://doi.org/10.1108/MIP-11-2019-0592

Simpson, A. (2008). Voluntary disclosure of advertising expenditures. Journal of Accounting, Auditing \& Finance, 23(3), 403436. https://doi.org/10.1177\%2F0148558X0802300306

Srivastava, R. K., Shervani, T. A., \& Fahey, L. (1998). Marketbased assets and shareholder value: A framework for analysis. Journal of Marketing, 62(1), 2-18. https://doi.org/10.2307/1251799

Stewart, D. W. (2009). Marketing accountability: Linking marketing actions to financial results. JournalofBusiness Research, 62(6), 636-643. https://doi.org/10.1016/j.jbusres.2008.02.005

Sydney-Hilton, E., \&Vila-Lopez, N. (2019). Are marketing strategies correlated with financial outputs? A longitudinal study. Journal of Business \& Industrial Marketing, 34(7), 15331546. https://doi.org/10.1108/JBIM-02-2018-0088

Verrecchia, R. E. (2001). Essays on disclosure. Journal of Accounting and Economics, 32(1), 97-180. https://doi.org/10.1016/S0165-4101(01)00025-8 


\section{Authorship}

\section{Evelini Lauri Morri Garcia*}

Universidade Estadual de Maringá, Programa de Pós-graduação em Ciências Contábeis

Av. Colombo, n. 5790, 87020-900, Zona 7, Maringá, PR, Brazil

E-mail address: elmgarcia@uem.br

(1) https://orcid.org/0000-0003-4321-8643

\section{Valter Afonso Vieira}

Universidade Estadual de Maringá, Programa de Pós-graduação em Administração

Av. Colombo, n. 5790, 87020-900, Zona 7, Maringá, PR, Brazil

E-mail address: vavieira@uem.br

(1) https://orcid.org/0000-0002-4129-3343

\section{Caroline Pereira Borges}

Universidade Estadual de Maringá, Programa de Pós-graduaçáo em Administração

Av. Colombo, n. 5790, 87020-900, Zona 7, Maringá, PR, Brazil

E-mail address: caroline-borges@outlook.com.br

(1) https://orcid.org/0000-0002-0641-3880

* Corresponding Author

\section{Funding}

The authors reported that there is no financial support for the research in this article.

\section{Conflict of Interests}

The authors have stated that there is no conflict of interest.

\section{Copyrights}

RAC owns the copyright to this content.

\section{Plagiarism Check}

The RAC maintains the practice of submitting all documents approved for publication to the plagiarism check, using specific tools, e.g.: iThenticate.

\section{Authors' Contributions}

$1^{\text {st }}$ author: conceptualization (equal); data curation (equal); formal analysis (equal); investigation (equal); methodology (equal); project administration (equal); software (equal); supervision (equal); validation (equal); writing-original draft (equal); writing-review \& editing (supporting).

$2^{\text {nd }}$ author: conceptualization (equal); data curation (equal); formal analysis (equal); investigation (equal); methodology (equal); project administration (equal); software (equal); supervision (equal); validation (equal); writing-original draft (equal); writing-review \& editing (lead).

$3^{\text {rd }}$ author: data curation (supporting); methodology (supporting); project administration (supporting); visualization (supporting).

\section{Peer Review Method}

This content was evaluated using the double-blind peer review process. The disclosure of the reviewers' information on the first page, as well as the Peer Review Report, is made only after concluding the evaluation process, and with the voluntary consent of the respective reviewers and authors.

\section{Data Availability}

The authors claim that all data and materials have been made publicly available through the Mendeley Data platform and can be accessed at:

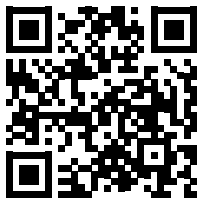

Garcia, Evelini Lauri Morri; Vieira, Valter Afonso; Borges, Caroline Pereira, 2021, "Replication Data for: Marketing investment information: differentiation resource or secret? published by RAC-Revista de Administraçáo Contemporânea", Harvard Dataverse, V1. https://doi.org/10.7910/DVN/VRXMLK

RAC encourages data sharing but, in compliance with ethical principles, it does not demand the disclosure of any means of identifying research subjects, preserving the privacy of research subjects. The practice of open data is to enable the reproducibility of results, and to ensure the unrestricted transparency of the results of the published research, without requiring the identity of research subjects. 


\section{APPENDIX A.}

Table A1. Marketing investment information categories.

\begin{tabular}{|c|c|c|c|c|}
\hline Categories & Information & Source & $\begin{array}{l}\text { Information } \\
\text { type }\end{array}$ & $\begin{array}{l}\text { Information } \\
\text { perspective }\end{array}$ \\
\hline 1 & $\begin{array}{l}\text { Indication that there are marketing } \\
\text { assets and that they are off-balance } \\
\text { sheet assets }\end{array}$ & $\begin{array}{l}\text { IOSCO (Principles for Ongoing Disclosure } \\
\text { and Material Development Reporting by } \\
\text { Listed Entities - 1) and CPC } 26(13 ; 112)\end{array}$ & \multirow{2}{*}{ Qualitative } & \multirow{3}{*}{$\begin{array}{l}\text { Marketing } \\
\text { assets } \\
\text { (DivAM) }\end{array}$} \\
\hline 2 & $\begin{array}{l}\text { Indication of the different marketing } \\
\text { assets (for example, brand, customer } \\
\text { base, customer satisfaction, etc.) }\end{array}$ & $\begin{array}{l}\text { IOSCO (Principles for Ongoing Disclosure } \\
\text { and Material Development Reporting by } \\
\text { Listed Entities - 1) and CPC } 26(13 ; 112)\end{array}$ & & \\
\hline 3 & The estimated value of marketing assets & CPC 00 (QC7) & Quantitative & \\
\hline 4 & $\begin{array}{l}\text { Presence and types of marketing } \\
\text { investments }\end{array}$ & СРC $26(99 ; 101)$ & Qualitative & \multirow{3}{*}{$\begin{array}{l}\text { Marketing } \\
\text { investments } \\
\text { (DivIM) }\end{array}$} \\
\hline 5 & Annual marketing investment value & СРС 00 (99) - CPC 26 (QC7) & Quantitative & \\
\hline 6 & $\begin{array}{l}\text { Percentage change in marketing } \\
\text { investment compared to the previous } \\
\text { year }\end{array}$ & $\begin{array}{l}\text { CPC } 00 \text { (QC21) - CPC } 26(13 ; 38 ; 43 ; 113) \\
\text { - IASB (Publishes Discussion Paper on } \\
\text { Management Commentary) }\end{array}$ & \multirow{4}{*}{ Quantitative } & \\
\hline 7 & $\begin{array}{l}\text { Variation in net revenue for the } \\
\text { year linked exclusively to marketing } \\
\text { investments }\end{array}$ & $\begin{array}{l}\text { CPC } 00 \text { (QC21) - CPC } 26(13 ; 38 ; 43 ; 113) \\
\text { - IASB (Publishes Discussion Paper on } \\
\text { Management Commentary) }\end{array}$ & & \multirow{3}{*}{$\begin{array}{l}\text { Financial and } \\
\text { economic } \\
\text { effects of } \\
\text { marketing } \\
\text { investments } \\
\text { (DivRFE) }\end{array}$} \\
\hline 8 & $\begin{array}{l}\text { Change in net income for the year } \\
\text { linked exclusively to marketing } \\
\text { investments }\end{array}$ & $\begin{array}{l}\text { CPC } 00 \text { (QC21) - CPC } 26(13 ; 38 ; 43 ; 113) \\
\text { - IASB (Publishes Discussion Paper on } \\
\text { Management Commentary) }\end{array}$ & & \\
\hline 9 & $\begin{array}{l}\text { Change in market value linked } \\
\text { exclusively to marketing investments }\end{array}$ & $\begin{array}{l}\text { CPC } 00(\mathrm{QC} 21)-\text { CPC } 26(13 ; 38 ; 43 ; 113) \\
\text { - Publishes Discussion Paper on } \\
\text { Management Commentary) }\end{array}$ & & \\
\hline 10 & $\begin{array}{l}\text { Outlook that current year's marketing } \\
\text { investments will influence economic } \\
\text { and/or financial results for the coming } \\
\text { years }\end{array}$ & $\begin{array}{l}\text { CPC } 26 \text { (13) — IASB (Publishes Discussion } \\
\text { Paper on Management Commentary) }\end{array}$ & \multirow[t]{2}{*}{ Qualitative } & \multirow{3}{*}{$\begin{array}{l}\text { Future } \\
\text { economic } \\
\text { and financial } \\
\text { effects and } \\
\text { maintenance } \\
\text { of long-term } \\
\text { marketing } \\
\text { strategies } \\
\text { (DivFRFE) }\end{array}$} \\
\hline 11 & $\begin{array}{l}\text { Indication of marketing investments } \\
\text { for the next period }\end{array}$ & $\begin{array}{l}\text { IASB (Publishes Discussion Paper on } \\
\text { Management Commentary) }\end{array}$ & & \\
\hline 12 & $\begin{array}{l}\text { Estimated value for marketing } \\
\text { investments for the next period }\end{array}$ & CPC 00 (QC7) & Quantitative & \\
\hline
\end{tabular}

